\title{
THE NEW FEATURES OF LANDSLIDE RELIEF DISCOVERED USING LIDAR - CASE STUDY FROM BABIA GÓRA MASSIF, WESTERN CARPATHIAN MOUNTAINS
}

\author{
Adam ŁajCZaK ${ }^{1}$, Barbara CZajKa², Ryszard J. KaczKa ${ }^{2}$ \\ ${ }^{1}$ Institute of Geography, Pedagogical University of Cracow, Poland \\ ${ }^{2}$ Faculty of Earth Sciences, University of Silesia, Sosnowiec, Poland \\ Manuscript received: May 30, 2014 \\ Revised version: July 28, 2014
}

ŁajcZak A., CZajKa B., KaczKa R.J., 2014. The new features of landslide relief discovered using LiDAR - case study from Babia Góra massif, Western Carpathian Mountains. Quaestiones Geographicae 33(3), Bogucki Wydawnictwo Naukowe, Poznań, pp. 77-88, 11 figs. DOI 10.2478/quageo-2014-0031, ISSN 0137-477X.

\begin{abstract}
AвSTRACT: Basing on LiDAR data, the re-interpretation of the limit and distribution of the selected landslide forms in 9 test areas were carried out. The forms are located at the slopes of the monoclinal ridge of Babia Góra Mt. (1,725 m a.s.1.) in the flysch Western Carpathians. The earlier knowledge on these landforms is shown in the unpublished map at the scale of 1:5,000 which was prepared basing on geomorphological mapping. Basing on the newest information source, subtle geomorphic signatures of landslides were found, the dynamics of these forms and directions of their further development were determined. Local differentiation of deep-seated landslides was indicated according to the relation between the sandstone layer dip and slope inclination, slope length, and altitude of the location of headwaters. An attention was paid to polycyclic relief of the highest located landslide forms, which contain the elements of glacial and nival morphology, and some are modelled by debris flows.
\end{abstract}

KEY WORDS: LiDAR data, geomorphological mapping, landslides, Babia Góra massif, Western Carpathian Mountains

Address of the corresponding author: Adam Łajczak, Institute of Geography, Pedagogical University of Cracow, Podchorażych 2, 30-084 Kraków, Poland; e-mail: alajczak@02.pl

\section{Introduction}

LiDAR (Light Detection and Ranging) or ALS (Airborne Laser Scanning) is the modern laser-based remote sensing which started in 1970s, and in common use has been since the late 1990s. In Poland this new proxy is used mostly in archaeology (Zapłata, Sławik 2011), meteorology (Zwoździak et al. 2001), hydrology (Malinger et al. 2013) and geomorphology where its highest potential is connected with detailed analyses of processes and reliefs, and geomorphological mapping (Migon et al. 2013). The relief of mountain areas is the most difficult to detect and LiDAR data are helpful to re-interpret landforms and pattern of their evolution, for example in the Karkonosze Mts (Knapik et al. 2009), Stołowe Mts (Wojewoda et al. 2011) and in the Tatra Mts (Wójcik et al. 2013). With those data it is possible to recognize subtle geomorphic signatures of landslides (Borkowski et al. 2011, Wojciechowski et al. 2012).

The aim of this work was to explore the potential use of LiDAR as a data to analyse of landforms at Babia Góra massif, the flysch Carpathian Mountains. These kind of analysis allows to re-interpret the limits, structure and complexity of the selected landslides. The comparison of the limit and configuration of the investigated landforms based on both the newest and the traditional in- 
formation sources indicates how the most modern measuring techniques may change the knowledge of the slope relief influenced by landslides and other geomorphological processes.

\section{Study area}

The monoclinal ridge of Babia Góra Mt. (1,725 $\mathrm{m}$ a.s.l.) is the highly located massif in the flysch Western Carpathians reaching the height of 1,100 $\mathrm{m}$ above the surrounding areas. The ridge located along the $\mathrm{W}$-E direction is $10 \mathrm{~km}$ long (Fig. 1). The upper part of the ridge (above 1,000 $\mathrm{m}$ a.s.l.) is built of Magura sandstone layers dipping to the south, and the lower part consists of less resistant folding sub-Magura layers (Książkiewicz 1983, Alexandrowicz 2004). Babia Góra massif consists of the zones of differentiated slope inclination: a) narrow ridge plateau with inclination usually below $10^{\circ}, \mathrm{b}$ ) the upper part of the southern slope with the average inclination $20^{\circ}$ which is similar to the dip of rock layers, c) the upper part of the northern slope (rocky slip of the cuesta) showing inclination $40^{\circ}-70^{\circ}, \mathrm{d}$ ) the base of rocky slip with inclination $10^{\circ}-30^{\circ}$, e) the lower parts of the northern and southern slopes cut by headwaters showing inclination up to $40^{\circ}$ (Eajczak 2012).

Large energy of the massif's relief and relatively poorly resistant bedrock favour development of broad structural landslides, which considerably influence the relief of the slopes of the massif, especially in the areas (c) and (e). The development of landslides is controlled by the distribution of fissures showing predominate directions NW-SE and SW-NE (Eajczak 2014). The commonly occurring landslide forms present in the whole area of the massif include: ridge and slope trenches with dilatation caves, escarpments, headwalls, rocky walls; and in the places covered by debris or block colluvia: hummocks and isolated hills, ramparts distributed similarly to contour-lines, tongues and wide lobes going down to spring sections of the valleys (Fig. 1).
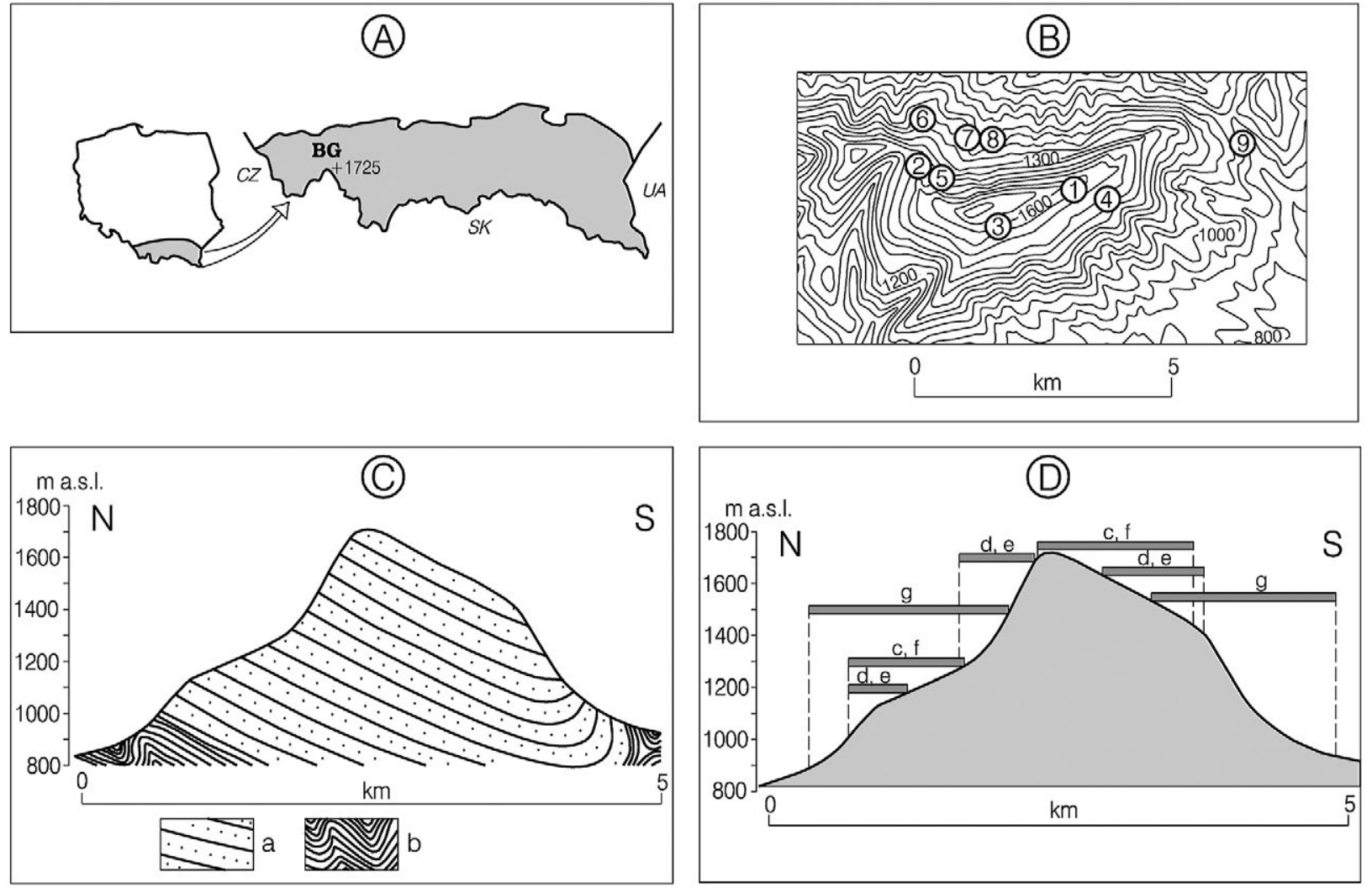

Fig. 1. Investigation area. A - location of Babia Góra massif. B - hypsometry of the massif and location of test areas (1-9). C - geological cross-section (N-S). D - height range of landslide forms at the northern and southern slopes of the massif. BG Babia Góra massif, a - Magura sandstone, b - sub-Magura layers. Landslide forms: $\mathrm{c}$ - ridge and slope trenches, $\mathrm{d}$ - escarpments, headwalls and rocky walls, e - colluvial hummocks and hills, $\mathrm{f}$ - colluvial ramparts, $\mathrm{g}$ - colluvial tongues and lobes 
Landslide headwalls in the cuesta, as opposed to the slope convergent with the dip of Magura sandstone, are deeper but their limit is smaller. They are accompanied by thicker covers of colluvia which build accumulation forms up to several tens of meters high.

\section{Methods of research}

The distribution and the range of landslide forms on the slopes of Babia Góra massif were determined basing on the contour-line map at the scale of 1:10,000 and on the orthophotomap of the raster size of $0.25 \mathrm{~m}$. Also the geomorphological map of the massif at the scale of 1:5,000 (Eajczak 1998a with latter revisions) was taken into account. This map was transformed with 1st affine type and with mean RMS $2.1 \mathrm{~m}$.

Basic information for re-interpretation of landslide relief of Babia Góra massif were obtained from the Aerial Laser Scanning data in 2012. The scanning was carried out with accuracy of 6 points at $1 \mathrm{~m}^{2}$ to the border of the Board of Babiogórski National Park and facilitated for the needs of the research project. Digital Elevation Model were computed using "bare Earth" data types from cloud points (*.las) of original resolution $0.5 \times 0.5$ m. Using ArcGIS 9.3 it was filtrated to eliminate information noise and re-interpolated to $1 \times 1 \mathrm{~m}$ model. For Babia Góra massif, which is relatively small area $\left(30 \mathrm{~km}^{2}\right)$ that was optimal resolution to detect most of the landslide forms. A slope reduction map and a hillshade model was prepared as a basic tool of relief analysis. Additionally the analysis of the curvature of a raster surface to detect convex and concave forms of the relief were performed. This was the base to determine the limits and configuration of the selected landslide forms which are the subject of this work. However linear and polygonal errors are visible on both models their shape made them easy to detect. Due to the size of the artefacts they do not influence the general picture of the relief. Investigated landforms were identifited and mapped employing on-screan mapping aided by elevation profiles. These analysis were supported by field observations.

All known elements of landslide relief occurring in the flysch Carpathians area are visible in the Babia Góra massif and they are located on slopes from the ridge plateau to the valley bottoms (Margielewski et al. 2008, Łajczak 2014). Nine test areas within the Babia Góra massif were selected for detailed analysis of landslide morphology of slopes, which are located at various elevations a.s.l. and which represent the distinguished zones of different slope inclination (Fig. 1B).

The (a) zone is represented by: (1) ridge trenches in the area of Zimna Dolinka, 1,500-1,580 m a.s.l., (2) ridge trenches in Izdebczyska area, $1,360-1,450 \mathrm{~m}$ a.s.l. The $(\mathrm{b})$ zone is represented by: (3) the headwall under the massif summit, the $S$ slope, 1,560-1,680 $\mathrm{m}$ a.s.l., (4) slope trenches under Kępa, the S slope, 1,410-1,500 m a.s.l. The (c) zone is represented by: (5) the headwall and colluvial tongue in Kościółki area, the $\mathrm{N}$ slope, 1,300-1,600 $\mathrm{m}$ a.s.l. The $(\mathrm{d})$ zone is represented by: (6) slope trenches in the area of Markowe Szczawiny, the N slope, 1,100-1,240 m a.s.l. Finally, the (e) zone is represented by: (7) headwall and colluvial tongue in Urwane area, the N slope, 1,060-1,200 m a.s.1., (8) colluvial lobe under Szeroki Żleb, the N slope, 1,050-1,320 m a.s.l., (9) the headwall and colluvial tongue in Dolina Sylca, the $\mathrm{S}$ slope, $880-1,080 \mathrm{~m}$ a.s.1.

\section{Investigation results}

The landforms in each of the test areas (Figs 2-10) are shown in the hillshade model map (A), slope reduction map (B), contour-line map (C) and orthophotomap (D). The picture of the terrain configuration is complemented with topographic profiles. The largest amount of information concerning the range and configuration of landslide forms in the each test area is obtained from information sources $\mathrm{A}$ and $\mathrm{B}$, which made it possible to specify geomorphological sketches of these areas, the archetype of which represents the unpublished geomorphological map of Babia Góra massif (Fig. 11).

In the test area No 1 (Figs 2,11) slope trenches occur which are separated by rocky packages formed as a result of gravitational tectonics of the massif. The landforms including the deepest trench and the adjacent rocky rampart show the orientation SW-NE and the secondary forms show the orientation NW-SE, which are both the 


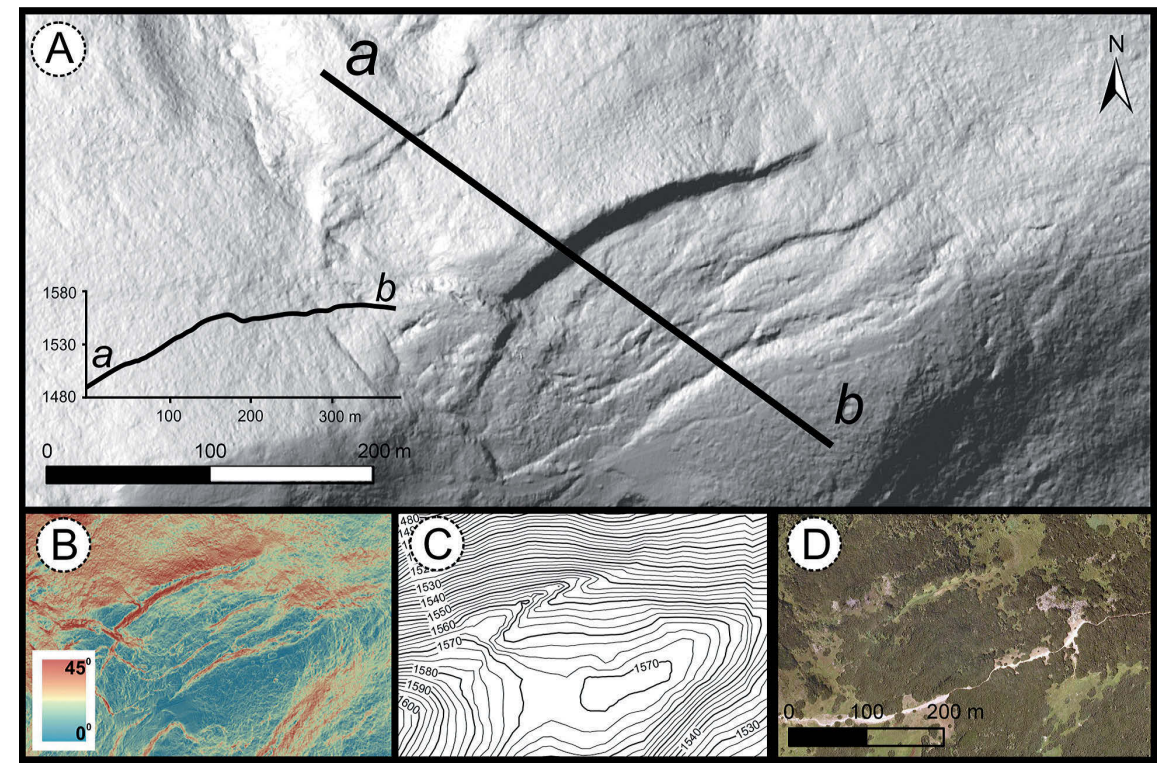

Fig. 2. Test area No 1. A - LiDAR image (a-b - topographic profile and its location), B - the map of slope reductions generated from LiDAR (range of slope reductions is given), C - contour-line map, D - orthophotomap. Maps B-D at the same scale, Map A at larger scale

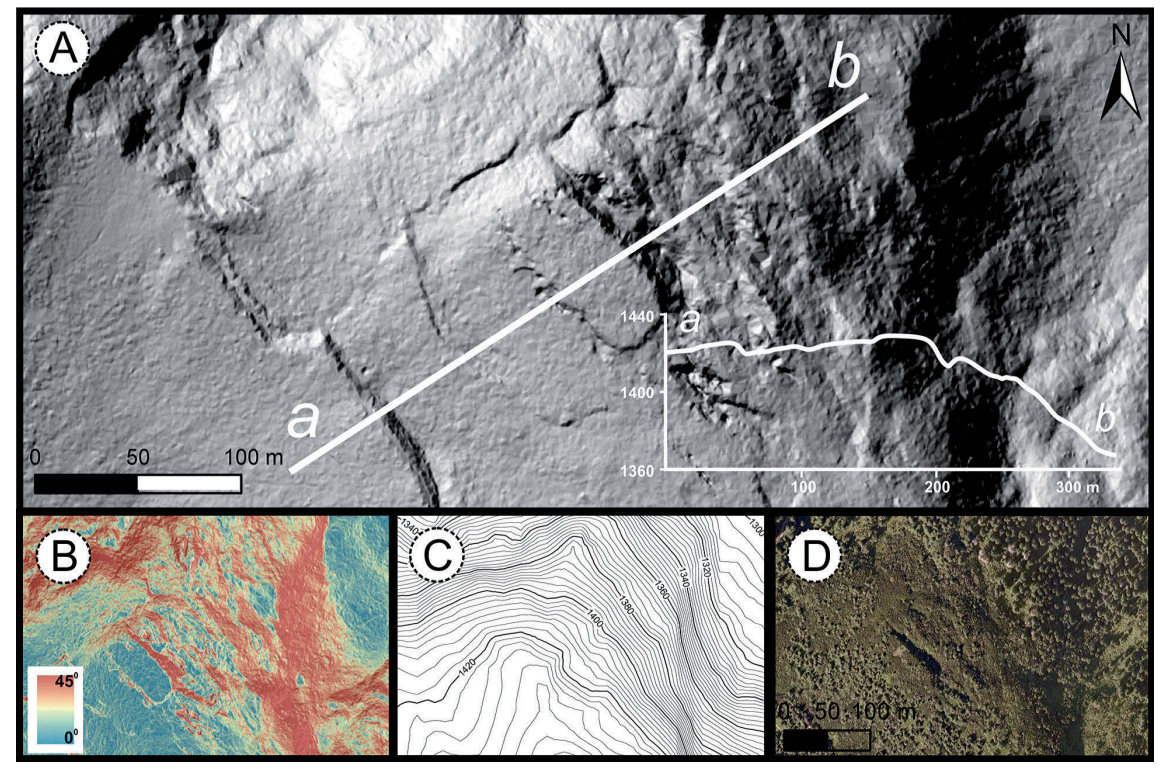

Fig. 3. Test area No 2. A - LiDAR image (a-b - topographic profile and its location), B - the map of slope reductions generated from LiDAR (range of slope reductions is given), C - contour-line map, D - orthophotomap. Maps B-D at the same scale, Map A at larger scale

directions along which landslide forms in Babia Góra massif develop (Eajczak 2014). The movement of rocky masses occurs towards the northern slope of the massif. In the upper part of this slope there is no much colluvium deposits which indicates an early stage of the development of ridge trenches in this area. On the other hand, the test area No 2 (Figs 3, 11) represents an advanced phase of development of ridge trenches. This part of the massif is mainly cut by fissures of NW-SE orientation with little fissuring of SWNE orientation, which was noticed by Alexandrowicz (1978). The movement of rocky packages towards the northern slope of the massif (to the NE) generates development of narrow and deep ridge trenches, the largest of which is $20 \mathrm{~m}$ deep (Zbójecki Wąwóz). The rocky packages on the slope are overthrown and scattered around producing a thick cover of colluvium blocks (Ziętarowie 1958). 


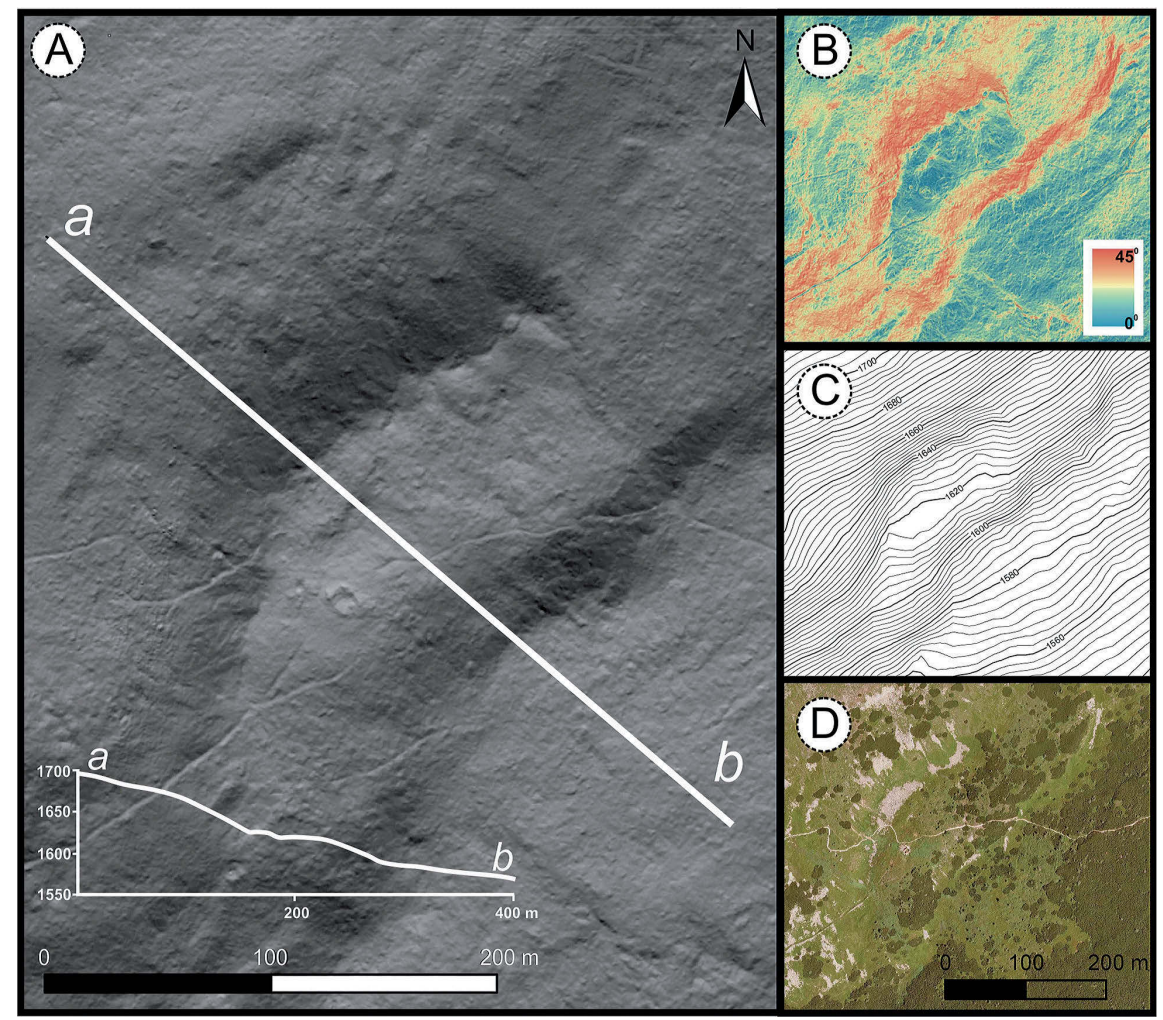

Fig. 4. Test area No 3. A - LiDAR image (a-b - topographic profile and its location), B - the map of slope reductions generated from LiDAR (range of slope reductions is given), C - contour-line map, D - orthophotomap. Maps B-D at the same scale, Map A at larger scale

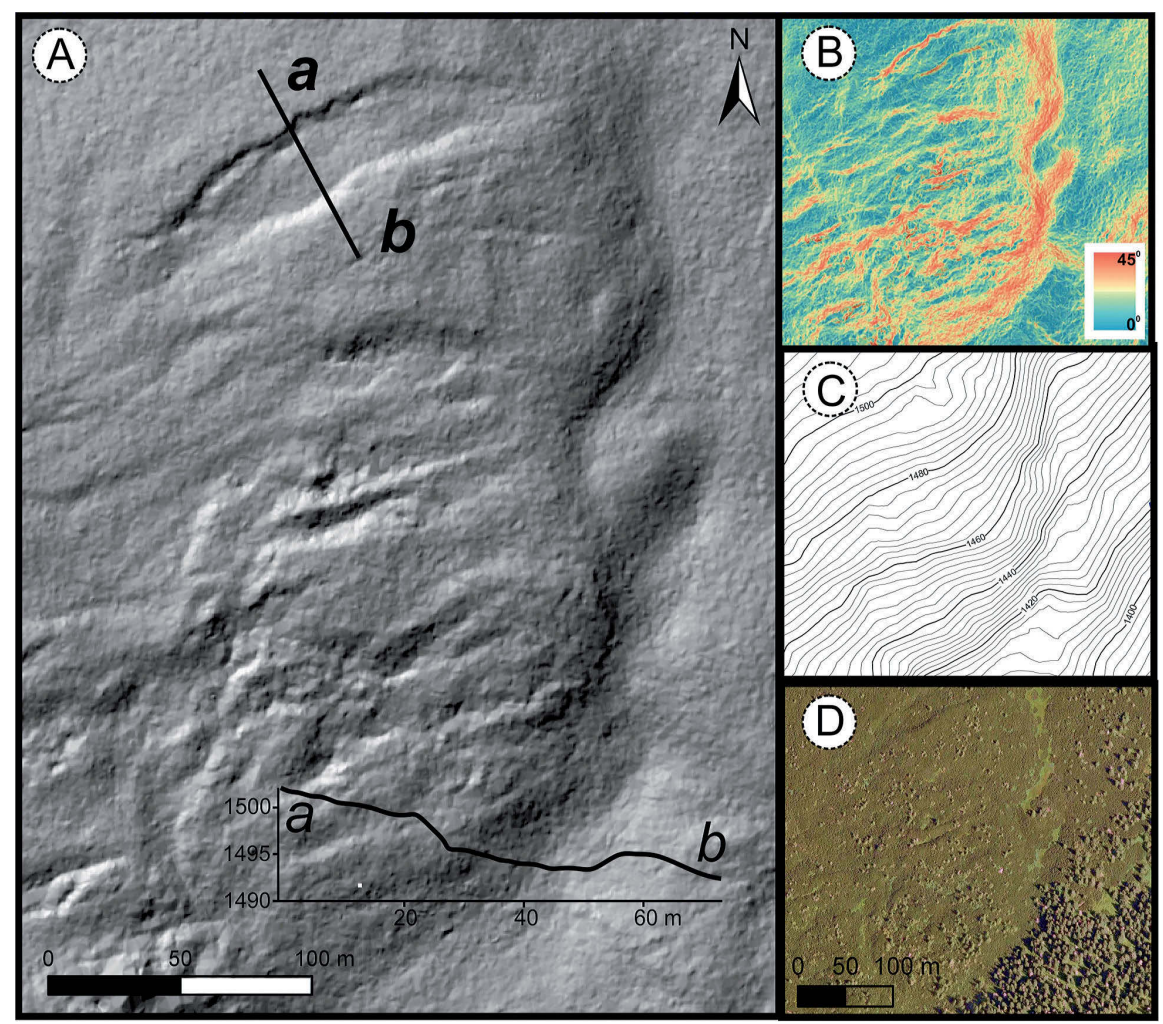

Fig. 5. Test area No 4. A - LiDAR image (a-b - topographic profile and its location), B - the map of slope reductions generated from LiDAR (range of slope reductions is given), C - contour-line map, D - orthophotomap. Maps B-D at the same scale, Map A at larger scale 
The test area No 3 (Figs 4, 11) contains escarpments on the southern slope of the massif showing the orientation SW-NE and also NW-SE, resulting from sliding of rocky packages in form of consequent layered (sliding) landslides. The central part is occupied by $50 \mathrm{~m}$ deep landslide headwall, and below there is a package of debris colluvia slid to the distance of only $100 \mathrm{~m}$. The headwall slopes are covered by creeping debris covers. In the headwall bottom at the slope foot there is an inactive nival rampart. The test area No 4 (Figs 5 and 11) represents a fragment of the southern slope of the massif with numerous parallel escarpments and slope trenches showing the orientation SW-NE. In the zone of detachment of rocky packages, a wide and $5 \mathrm{~m}$ deep slope trench occurs. Lower on the slope the concentration of escarpments and trenches increases and it is the highest just above the headwater, where the slope inclination is the highest in this test area. This may suggest that initiation of landslides in this part of Babia Góra massif occurs on the slopes of headwaters and their further development consists in activation of rocky packages located upper on the slope. This results in a regularity - the upper located landslide fragment, the younger its age is. This regularity was found in other parts of slopes in Babia Góra massif not included in this research (Łajczak 2014). The test area studied comprises a fragment of landslide headwall. Probably an initial form of the future headwall represents a slope trench occurring above (just at the topographic profile $a-b)$. A small depth of this potential headwall, similarly like the headwall located at the area No 3, is a typical feature of landslide headwalls located on the southern slope of Babia Góra massif.

In the test area No 5 (Figs 6, 11) located in the steep northern slope of the massif, a $70 \mathrm{~m}$ deep landslide headwall occurs. It is bordered with rocky slopes and below a broad colluvial tongue is present. On the surface of the colluvial tongue there are bow-shaped swellings separated by flatnesses and depressions. The edges of the headwalls and escarpments adjacent to the tongue and also some linear depressions on the debris cover of this tongue show orientation similar to main fissuring in Babia Góra massif (i.e. NW-SE, SW-NE), which evidences landside origin of this form. The colluvial tongue is adjacent to the west with the bottom of a glacial cirque, which is the largest one in the northern slope of the massif. A sharp border between the colluvial tongue and the cirque bottom occurs, which may suggest deposition of colluvia at the fringe of the glacier (Eajczak 1998b). It is also possible that the colluvial tongue might have been functioning as debris glacier in the past. Also the morphology of the rocky headwall occurring above and showing distinct features of glacial transformation indicates older than Holocene age of this form. At the foot of rocky walls in this headwall and at its outlet, nival ramparts occur buried by debris cones. Similar forms are present in the adjacent headwall located above. The base of the colluvial tongue from the west represents a line which was reached by debris flows going down from the culmination of the massif and modelling at present the cirque's bottom. The lower located test area No 6 (Figs 7, 11) represents a less inclined fragment of the northern slope of the massif where (similarly to the highest located part of the massif) gravitation tectonics leads to spreading apart of rocky packages, development of escarpments and slope trenches, resulting in lowering and flattening of the slope. Numerous slope trenches and escarpments show orientation similar to the two main fissuring directions in the massif. Some of the trenches have rocky slopes and entrances to the dilatation caves. A thin colluvial cover does not disguise the relief conditioned by gravitation tectonics of the deeper substratum (Łajczak 2014).

The test area No 7 (Figs 8, 11) comprises a landslide which originated in 1868 in a broad headwater in the lower part of the northern slope of the massif. Over $50 \mathrm{~m}$ deep landslide headwall is developed on the Magura sandstone outcrops and the colluvial tongue consists of rocky blocks reaching $5 \mathrm{~m}$ in diameter. The narrow shape of the tongue matches to the morphology of the valley bottom, and the barrier in its development represents an edge of a high terrace from one side and a front of the colluvial lobe from the other side. The exposure of shallow occurring outcrops of the Magura sandstone in the headwall of this landslide (similarly to the described above test area) makes it possible to question the view of a large thickness of the colluvial cover in the lower part of the northern slope of Babia Góra massif (Alexandrowicz 1978, Ziętara 2004). In the adja- 


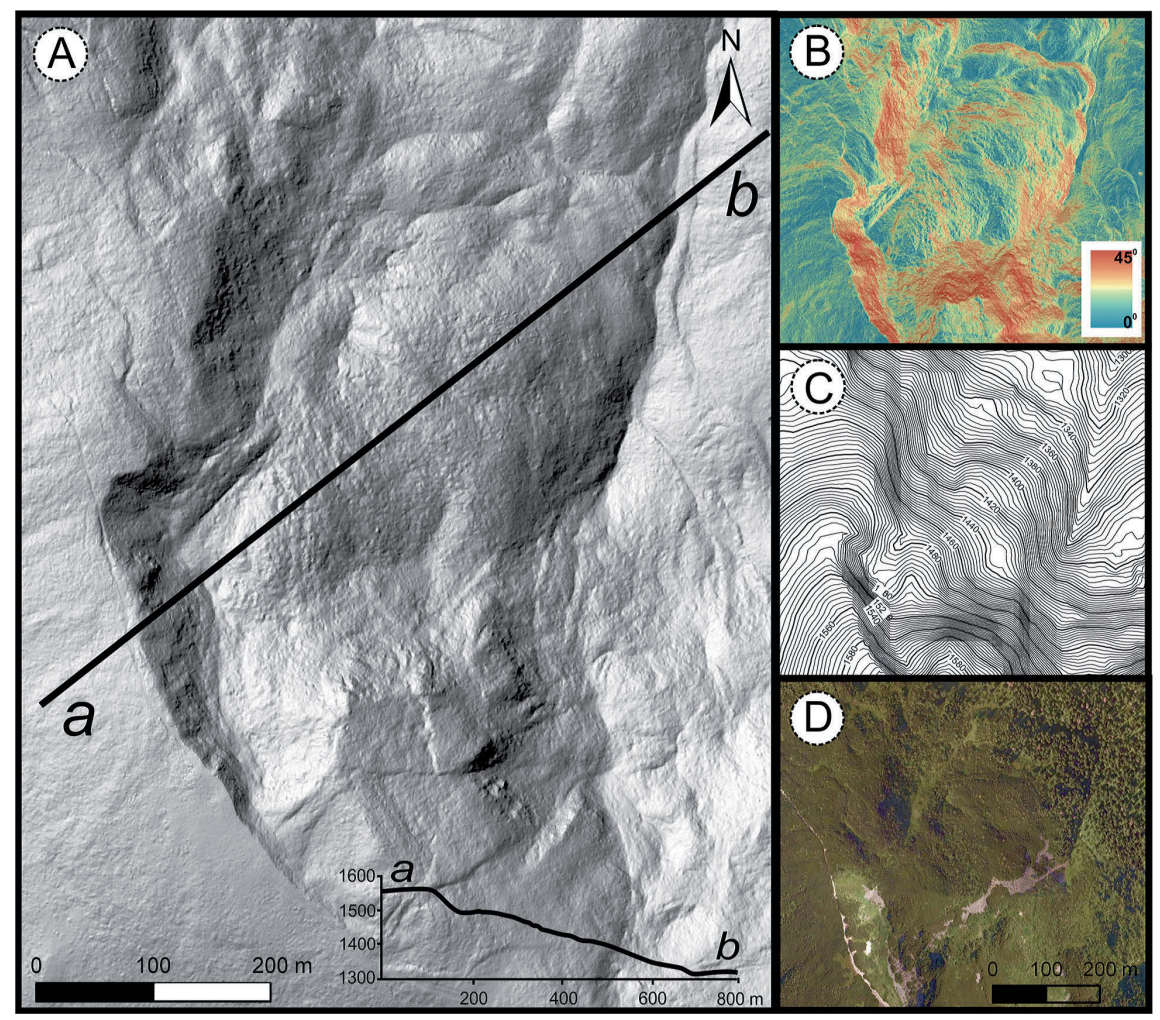

Fig. 6. Test area No 5. A - LiDAR image (a-b - topographic profile and its location), B - the map of slope reductions generated from LiDAR (range of slope reductions is given), C - contour-line map, D - orthophotomap. Maps B-D at the same scale, Map A at larger scale

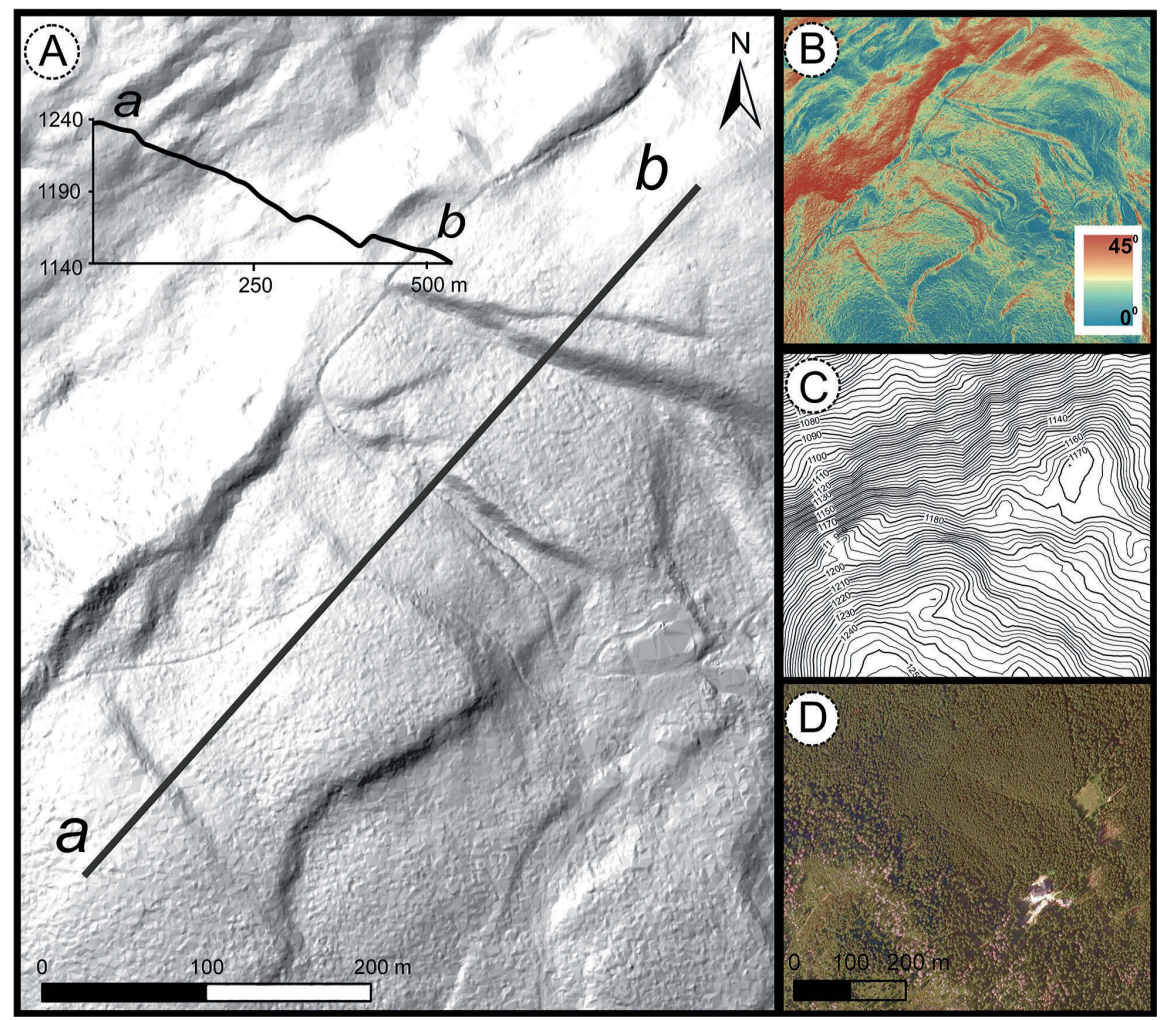

Fig. 7. Test area No 6. A - LiDAR image (a-b - topographic profile and its location), B - the map of slope reductions generated from LiDAR (range of slope reductions is given), C - contour-line map, D - orthophotomap. Maps B-D at the same scale, Map A at larger scale 


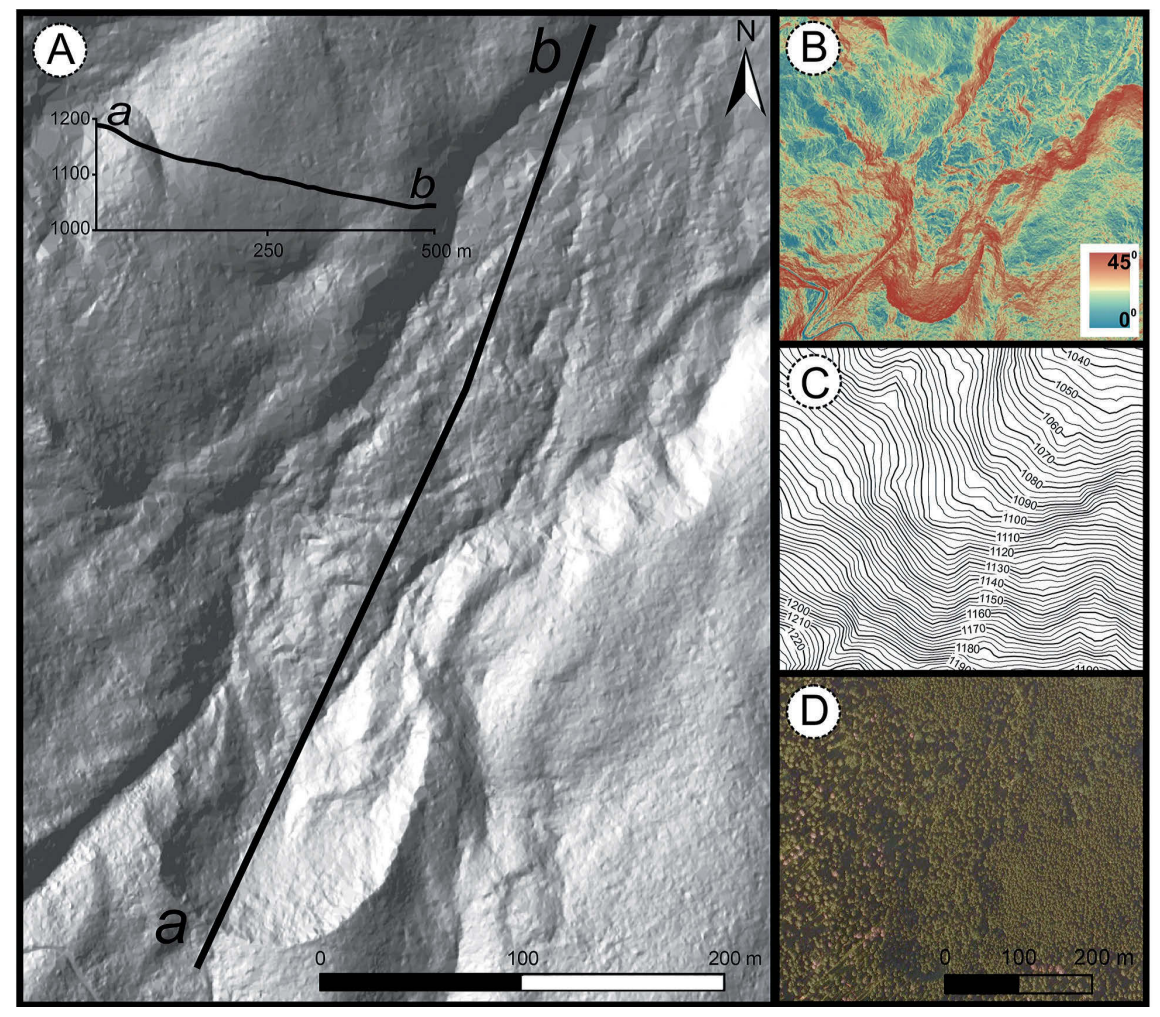

Fig. 8. Test area No 7. A - LiDAR image (a-b - topographic profile and its location), B - the map of slope reductions generated from LiDAR (range of slope reductions is given), C - contour-line map, D - orthophotomap. Maps B-D at the same scale, Map A at larger scale

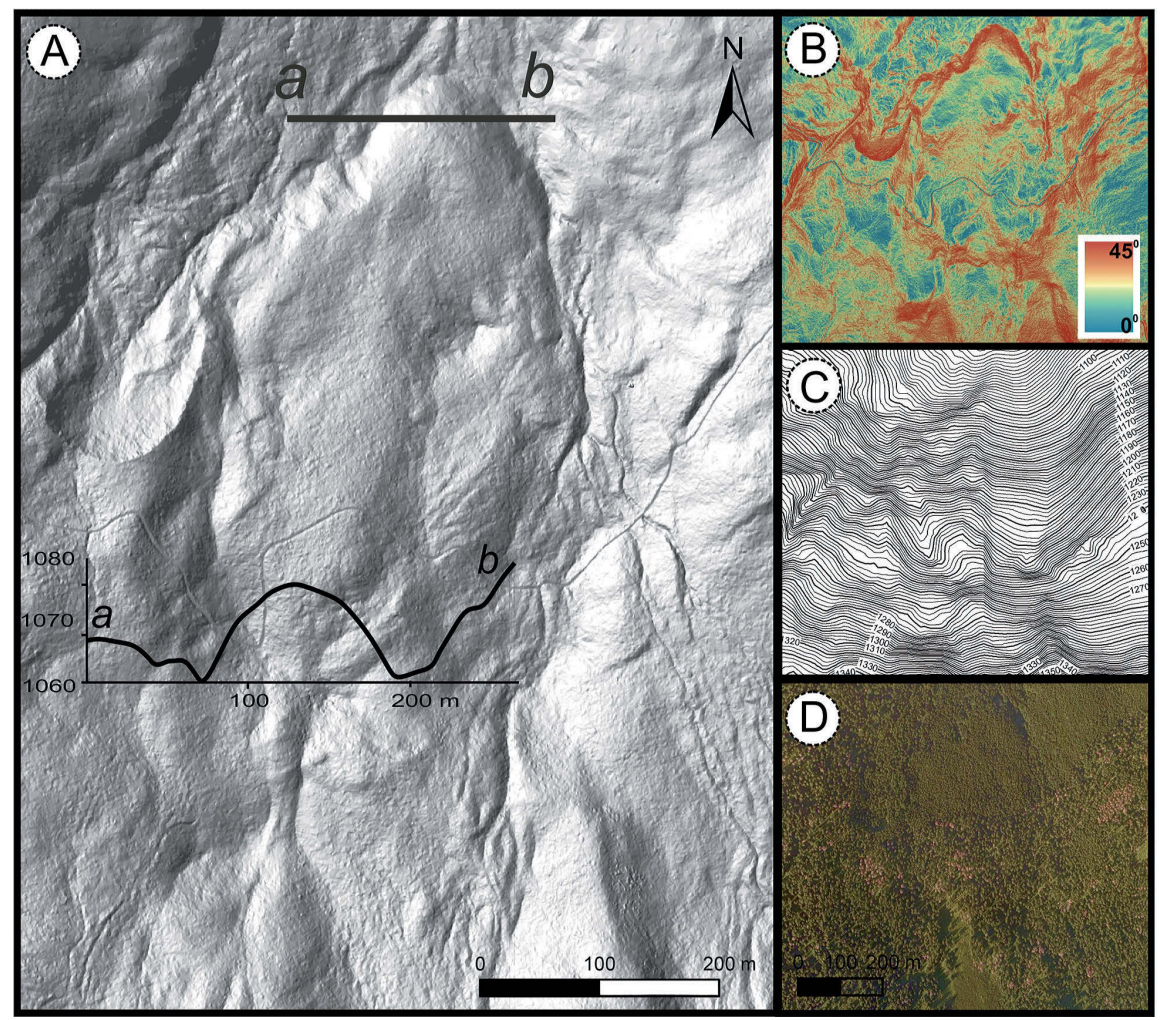

Fig. 9. Test area No 8. A - LiDAR image (a-b - topographic profile and its location), B - the map of slope reductions generated from LiDAR (range of slope reductions is given), C - contour-line map, D - orthophotomap. Maps B-D at the same scale, Map A at larger scale 


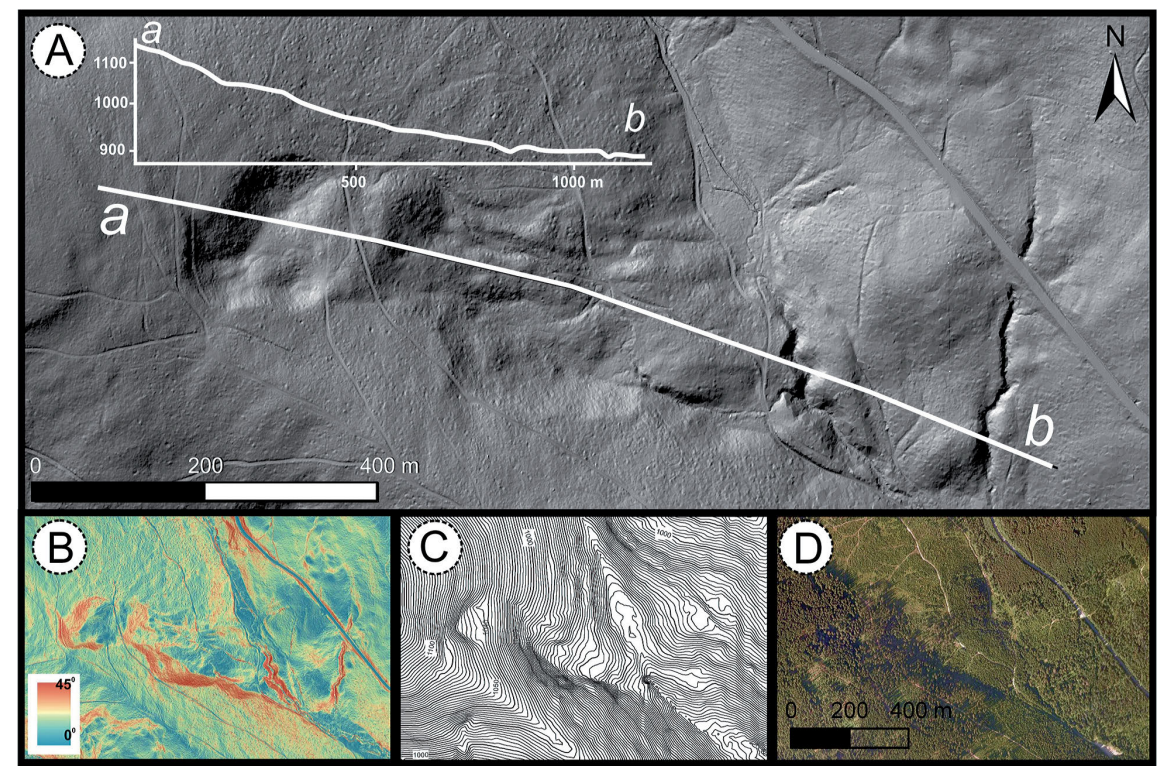

Fig. 10. Test area No 9. A - LiDAR image (a-b - topographic profile and its location), B - the map of slope reductions generated from LiDAR (range of slope reductions is given), C - contour-line map, D - orthophotomap. Maps B-D at the same scale, Map A at larger scale

cent test area No 8 (Figs 9, 11) the largest colluvial lobe in the massif occurs. Debris material which build this form was transported from an extensive denudation form located on the northern slope of the massif and reaching the summit area. The colluvial lobe widely enters an upper part of the valley. Steep and over $30 \mathrm{~m}$ high front of this form consists of secondary lobes. In the lobe configuration, three long bumps are visible suggesting separate flows of transportation of debris colluvia. The eastern edge of the lobe is modelled by debris flows.

In the test area No 9 (Figs 10,11) a unique geomorphological situation in the massif of Babia Góra occurs, i.e. clenching of the valley bottom by landslides going down from its both sides. The stream creates there a gorge which is cut not at the border of both colluvial tongues but across the longer tongue. Other streams cut their gorges at the border of both colluvial tongues. The landslides are active, which is evidenced by damages in the neighbouring road. Above the junction of colluvial tongues a flatness in the valley bottom occurs which is the only trace in Babia Góra massif of former landslide lake of dam genesis filled with fluvial material. The longitudinal profile of the main stream is uneven. The steepest section of stream channel cutting across the colluvia has not reached a terrain flatness in the place of material deposition in the former lake.

\section{Discussion of results and conclusions}

The relief of test areas reflects geomorphological problems typical for the larger fragments of Babia Góra massif and indicates a predominated role of landslides in modelling the massif relief (Eajczak 1998a, 2014). The mechanism of landslide development reflected in their morphology, which detailed analysis was possible with the use of LiDAR data, is typical for landslides from other areas described by eg. Hutchinson (1988, 1995), Cruden and Varnes (1996), Dikau et al. (1996), Margielewski et al. (2008). Development of landslides in the massif of Babia Góra Mt. is initiated in the low-located or the highest located slope fragments. The former of these situations is connected with headward erosion in headwaters and it is represented by the test areas No 4 and 6-9. Because of the fact that the headwaters at Babia Góra Mt. are located in lower parts of the slopes, the development of landslides generated this way does not comprise the upper located parts of the slopes. In other areas of the flysch Carpathians the development of headwaters comprising almost the whole height ranges of slopes generates development of landslides even within the highest steep slopes (Margielewski 2006, Margielewski et al. 2008, Alexandrowicz, Margielewski 2010). Development of deep-seated landslides in Babia Góra Mt. including ridge 

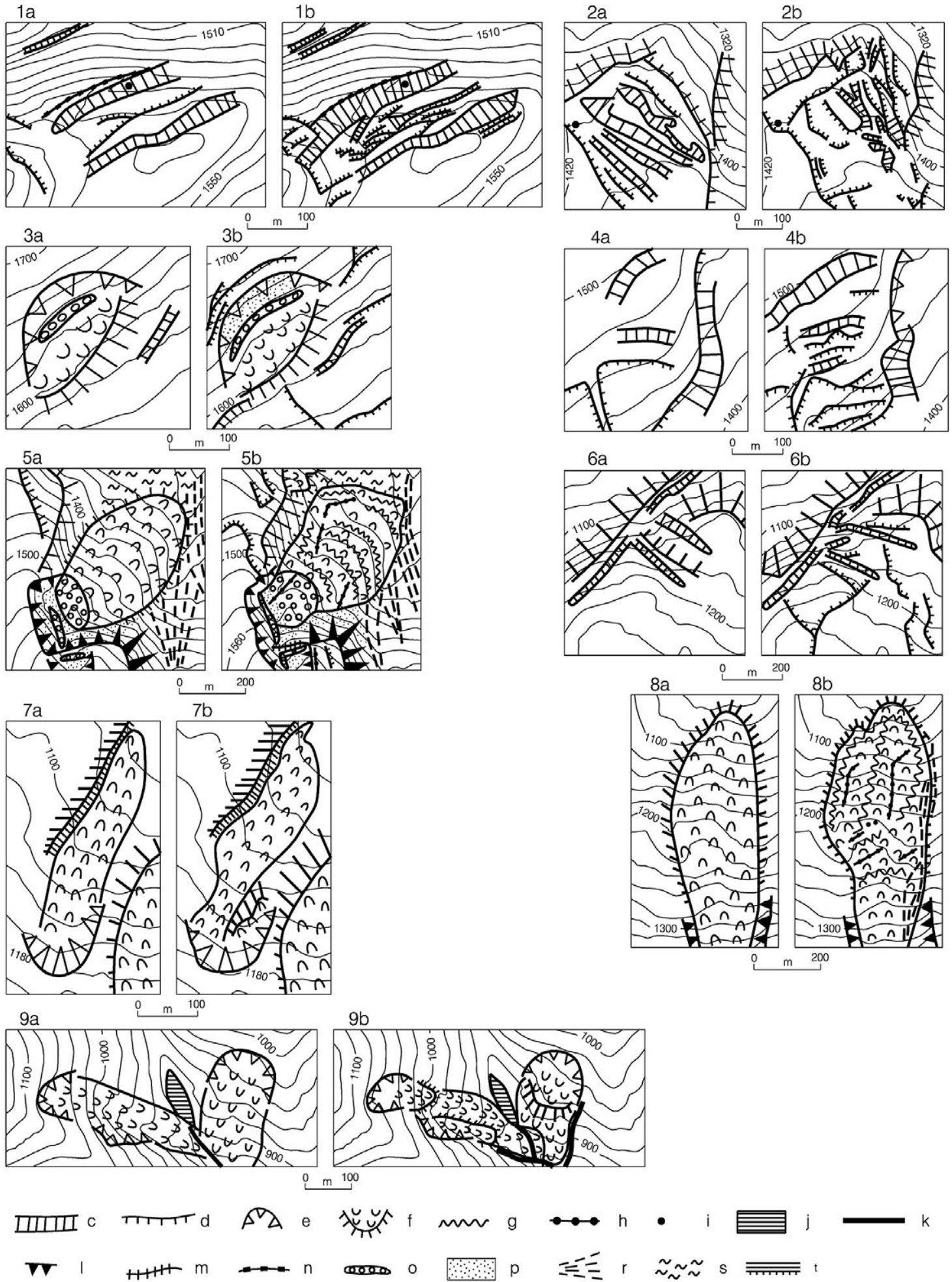

Fig. 11. Comparison of the limit of landslide forms and forms of other origin in the test areas 1-9 basing on: a - geomorphological map of Babia Góra Mt., b - LiDAR images. Shaded Relief map, c - ridge and slope trenches, d - landslide escarpments, e - landside headwalls, $\mathrm{f}$ - colluvial tongues, $\mathrm{g}$ - axes of linear swellings on colluvial tongues, $\mathrm{h}$ - axes of linear depressions on colluvial tongues, $\mathrm{i}$ - landslide lakes, $\mathrm{j}$ - flat valley bottom in the place of deposit filling of former landslide lake, $\mathrm{k}$ - gorges of streams cutting across the landslide tongues, 1 - steep slopes in the place of glacial undercutting, $\mathrm{m}$ convex bend between glacially re-modelled headwalls located at different heights, $\mathrm{n}$ - sharp rocky crest, $\mathrm{o}$ - nival rampart (inactive), $\mathrm{p}$ - debris slope, $\mathrm{r}$ - torrential cones with fossil debris flows, $\mathrm{s}$ - moraines degraded by landslides, $\mathrm{t}$ - high terrace 
plateau and the highest parts of the slopes (despite their inclination) is initiated by deep fissuring in the sandstone, along which ridge or slope trenches develop at first. Such situation is represented by the test areas No 1-3 and 5. At the slope of cuesta type, the colluvia are transported at larger distances than in case of the less inclined slope which is concordant to the dip of sandstone layers (compare the test areas No 5, 7, 8 and 3,4). Colluvial tongues which reach the valley bottoms cause large changes in their morphology (the test areas No 7-9). The highest located landslides at Babia Góra Mt. show polycyclic relief. It is represented by the test areas No 3 and, especially No 5, which contain elements of glacial and/or nival morphology. Some colluvial tongues or the adjacent areas have been locally re-modelled by debris flows (the test areas No 5, 8).

Employment of LiDAR data is resulted by developing more detailed image of the uncovering real surface. Forest and lower vegetation cover is one of the major problem in geomorphological mapping of investigated area. In all nine test areas the general character and limit of the landforms were known but new features of landslide morphology were discovered (Fig. 11: 1, 3, 4, 6). Re-interpretation of the landforms was mainly related to the shape of landslides (Fig 11: 2, 5, 7, 8 and 9).

Despite the fact that landslide relief of Babia Góra Mt. has been investigated for over 100 years (Rehman 1895, Ziętarowie 1958, Alexandrowicz 1978, Łajczak 1998b, 2012, 2014, Ziętara 2004), a geomorphological map of this massif has not been published. It is necessary to re-interpret the relief of the whole massif basing on LiDAR data including all the landslide forms. Other information sources considered in the work will have only secondary importance.

\section{Acknowledgements}

The Authors would like to thank the Board of Babiogórski National Park for the access to data of the Airborne Laser Scanning. The work has been completed in the frames of MNiSW grant $\mathrm{N}$ N306 070640 (years 2011-2014) "Natural and anthropogenic conditions of the distribution of the upper timber limit in Babia Góra massif and its dynamics in the last 200 years".

\section{References}

Alexandrowicz S.W., 1978. The northern slope of Babia Góra Mt. as a huge rock slump. Studia Geomorphologica Carpatho-Balcanica 12: 133-148.

Alexandrowicz S.W., 2004. Outlines of geology of the Babia Góra range. In: Wołoszyn B.W., Jaworski A., Szwagrzyk J. (eds), The Nature of Babiogórski National Park, Kraków: 87-107.

Alexandrowicz Z., Margielewski W., 2010. Impact of mass movements on geo- and biodiversity in the Polish Outer (Flysch) Carpathians. Geomorphology 123: 290-304.

Borkowski A., Perski Z., Wojciechowski T., Jóźków G., Wójcik A., 2011. Landslides mapping in Rożnów Lake vicinity, Poland, using Airborne Laser Scanning data. Acta Geodynamica et Geomaterialia 8(3): 325-333.

Cruden D.M., Varnes D.J., 1996. Landslide types and processes. In: Turner A.K., Schuster R.L. (eds), Landslides: investigation and mitigation. Transportation Research Board, Washington D.C., Special Report 247: 36-75.

Dikau R., Brunsden D., Schrott L., Ibsen M.L. (eds), 1996. Landslide recognition. Identification, movement and causes. Wiley, Chichester, pp. 251.

Hutchinson J.N., 1988. Morphological and geotechnical parameters of landslides in relation to geology and hydrogeology. In: Bonnard C. (ed.), Proc. of 5th Intern. Symp. on Landslides, 1. Balkena, Rotterdam: 3-35.

Hutchinson J.N., 1995. Deep-seated mass movements on slopes. Mem. Soc. Geol. Itn., 50: 147-164.

Knapik R., Jała Z., Sobczyk A., Migoń P., Aleksandrowski P., Szuszkiewicz A., Krąpiec M., Madej S., Krakowski K., 2009. Inventarisation and valorisation of geosites in Karkonosze National Park and its protection zone and realisation of geomorphological map of this area. Archive of the Karkonosze National Park.

Książkiewicz M., 1983. Outline of the geology of Mt. Babia Góra. In: Zabierowski K. (ed.), The Babiogórski National Park. Nature and Man, Kraków: 25-39.

Łajczak A., 1998a. Charakterystyka geomorfologiczna i wykonanie szczegótowej mapy geomorfologicznej (1:5000) Babiogórskiego Parku Narodowego (Geomorphological characteristics and realisation of detailed geomorphological map (1:5000) of the Babiogórski National Park). Plan Ochrony Babiogórskiego Parku Narodowego. Archiwum Babiogórskiego Parku Narodowego.

Łajczak A., 1998b. Występowanie form glacjalnych i niwalnych na Babiej Górze, Zachodnie Karpaty (Distribution of glacial and nival forms in the Babia Góra massif, Western Carpathians). Mat. IV Zjazdu Geomorfologów Polskich, Lublin, cz. I: 349-356.

Łajczak A., 2012. Water circulation and chemical denudation within the upper Skawica River flysch catchment, Western Carpathian Mountains. Zeitschrift für Geomorphologie 56: 69-86

Łajczak A., 2014. Relief development of the Babia Góra massif, Western Carpathians. Quaestiones Geographicae 33(1): 89-106.

Malinger A., Kałuża T., Grzonka B., Grzelka T., 2013. Possibilities of using LIDAR data in building a hydrodynamic flow model on the example of the Warta river section. Science, Nature, Technologies 7(1): 1-11.

Margielewski W., 2006. Structural control and types of movements of rock mass in anisotropic rocks: case study in the Polish Flysch Carpathians. Geomorphology 77: 47-68. 
Margielewski W., Święchowicz J., Starkel L., Łajczak A., Pietrzak M., 2008. Present-day evolution of the relief of the Flysch Carpathians. In: Starkel L., Kostrzewski A., Kotarba A., Krzemień K. (eds), Present-day changes in relief of Poland s territory, Kraków: 57-133.

Migoń P., Kasprzak M., Traczyk A., 2013. How high-resolution DEM based on airborne LIDAR helped to reinterpret landforms - examples from the Sudetes, SW Poland. Landform Analysis 22: 89-101.

Rehman A., 1895. Opis fizyczno-geograficzny ziem polskich $i$ sąsiednich krajów słowiańskich. Opis fizyczno-geograficzny Karpat (Physico-geographical description of the territory of Poland and neighbouring Slavonic countries. Physico-geographical description of the Carpathians). LwówKraków, pp. 250.

Wojciechowski T., Borkowski A., Perski Z., Wójcik A., 2012. Data from airborne laser scanning in investigation of landslides - example of the landslide in Zbyszyce (the External Carpathians). Przeglad Geologiczny 60: 95-102.

Wojewoda J., Białek D., Bucha M., Głuszyński A., Gotowała R., Krawczewski J., Schutty B., 2011. Geology of Góry Stołowe National Park - selected issues. In: Chodak T., Kabała C., Kaszubkiewicz J., Migoń P., Wojewoda J. (eds), Geoecologic conditions of natural environment of the Stołowe Mountains. WIND, Wrocław: 53-96.
Wójcik A., Wężyk P., Wojciechowski T., Perski Z., Maczuga S., 2013. Geological and geomorphological interpretation of data of airborne laser scanning (ALS) in the area of Kasprowy Wierch (The Tatras). Przeglad Geologiczny 61: 234-242.

Zapłata R., Sławik Ł., 2011. Laser-based remote sensing in study and secure of national archeological heritage. In: Jasiewicz J., Lutyńska M., Rzeszewski M., Szmyt M., Makohonienko M. (eds), Geoinformation methods in archaeological investigations, Poznań: 89-90.

Ziętara T., 2004. Surface features of Mt. Babia Góra. In: Wołoszyn B.W., Jaworski A., Szwagrzyk J. (eds), The Nature of Babiogórski National Park, Kraków: 109-135.

Ziętarowie K. i T., 1958. O rzekomo glacjalnej rzeźbie Babiej Góry (About supposedly glacial relief of Babia Góra massif). Roczn. Nauk.-Dydakt. WSP, Kraków, Geografia, 8: $55-78$.

Zwoździak J., Zwoździak A., Sowka I., Ernst K., Stacewicz T., Szymański A., Chudzyński S., Czyżewski A., Skubiszak W., Stelmaszczyk K., 2001. Some results on the ozone vertical distribution in atmospheric boundary layer from LIDAR and surface measurements over the Kamieńczyk Valley, Poland. Atmospheric Research 58(1): 55-70. 